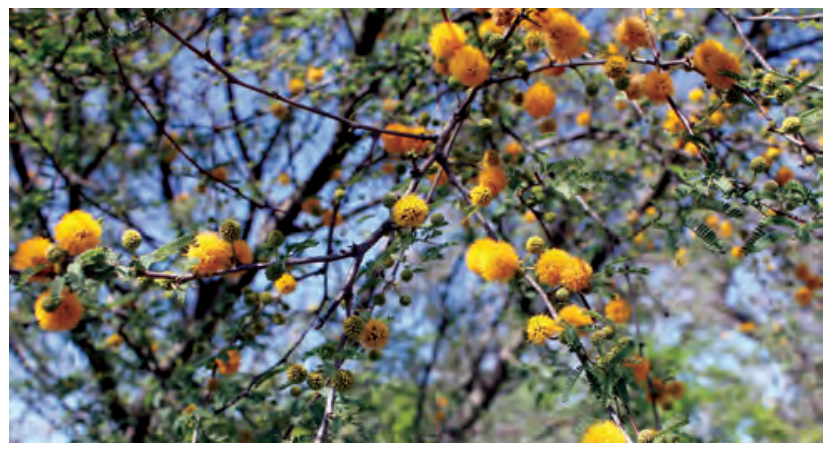

COMMON WOODY PLANTS AND CACTI OF SOUTH TEXAS 


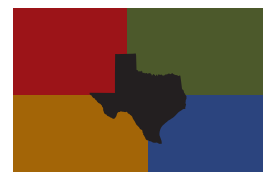

TEXAS NATURAL HISTORY GUIDES ${ }^{\text {TM }}$ 


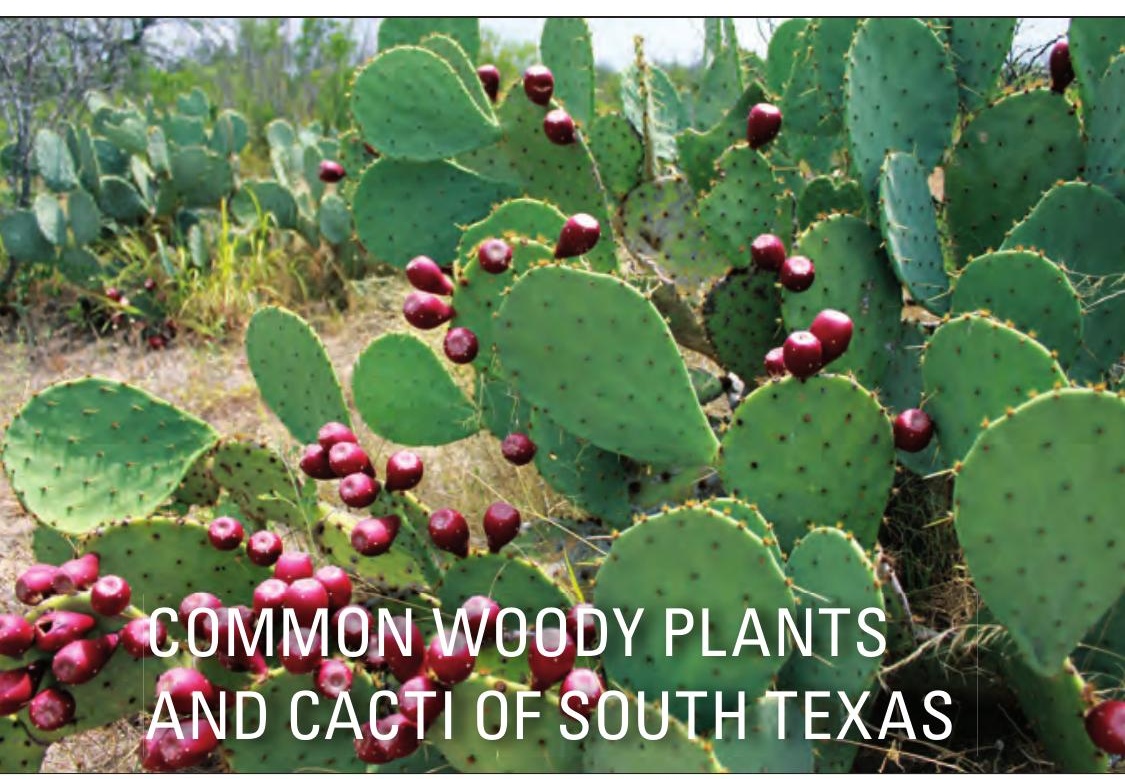

\section{A FIELD GUIDE}

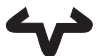

UNIVERSITY OF TEXAS PRESS Austin 
Photos are by Richard B. Taylor

Copyright (C) 2014 by Richard B. Taylor and Texas Parks and Wildlife All rights reserved

Printed in China

First edition, 2014

Requests for permission to reproduce material from this work should be sent to:

Permissions

University of Texas Press

P.O. Box 7819

Austin, TX $78713-7819$

http://utpress.utexas.edu/index.php/rp-form

(0) The paper used in this book meets the minimum requirements of ANSI/ NISO Z39.48-1992 (R1997) (Permanence of Paper).

\section{LIBRARY OF CONGRESS CATALOGING-IN-PUBLICATION DATA}

Taylor, Richard B.

Common woody plants and cacti of South Texas : a field guide /

Richard B. Taylor. - First edition.

pages $\quad \mathrm{cm}-$ (Texas natural history guides)

Includes bibliographical references and index.

ISBN 978-0-292-75652-6 (pbk. : alk. paper)

1. Woody plants-Texas, South-Identification. 2. Cactus-Texas,

South-Identification. I. Title. II. Series: Texas natural history guides. QK188.T268 2014

$582.1^{\prime} 809764-\mathrm{dc} 23$ 
This book is affectionately dedicated to my dear wife and best friend, Lisa, for her unending love, support, patience, and encouragement throughout my wildlife career. 

Although brush may be brush to the casual observer, woody plants vary greatly in quality and value to both game and livestock.

VAL LEHMANN, FORGOTTEN LEGIONS: SHEEP IN THE

RIO GRANDE PLAINS OF TEXAS 
